\title{
Pola Penanganan Guru dalam Menghadapi Bullying di PAUD
}

\author{
Nanda Pratiwi ${ }^{1 凶}$, Sugito $^{2}$ \\ Pendidikan Anak Usia Dini, Universitas Negeri Yogyakarta, Indonesia(1) \\ Pendidikan Luar Sekolah, Universitas Negeri Yogyakarta, Indonesia(2) \\ DOI: $\underline{10.31004 / o b s e s i . v 6 i 3.1748}$
}

\begin{abstract}
Abstrak
Tujuan dari artikel ini adalah untuk melihat Pola Penanganan Guru Dalam Menghadapi Bullying di PAUD, apa bentuk tindakan yang di lakukan oleh guru dalam menanggapi bullying yang ada di sekolah. Pada lingkungan sekolah peran guru sangatlah penting dalam mengawasi anak dalam bersosialisasi antar teman sebayanya. Guru terkadang masih menganggap biasa beberapa perilaku anak didiknya yang mungkin tanpa disadari hal itu merupakan salah satu hal yang dapat memicu terjadinya bullying Pengetahuan dan juga kesadaran dari guru sangat dibutuhkan di dalam pencegahan terjadinya bullying ini, karna terkadang hal kecil saja dapat berdampak besar bagi perkembangan anak kedepannya. Penelitian ini di lakukan dengan menggunakan pendekatan kualitatif deskriptif melalui wawancara dan observasi secara langsung dengan enam orang guru di sekolah. Ternyata berdasarkan wawancara dan observasi tersebut di dapatkan beberapa bentuk penanganan yang dilakukan guru dengan rata-rata bentuk penanganan yang hampir sama antar satu guru dengan guru lainnya. Hal ini di harapkan mampu menjadi salah satu bentuk informasi bagi guru di dalam menghadapi bullying yang ada di sekolah.
\end{abstract}

Kata-kata Kunci: bullying; anak tk; sekolah

\begin{abstract}
The purpose of this article is to look at the pattern of teacher handling in dealing with bullying in PAUD, what forms of action are taken by teachers in responding to bullying in schools. In the school environment, the teacher's role is very important in supervising children in socializing among their peers. Teachers sometimes still take it for granted that some of the behavior of their students may be unwittingly one of the things that can trigger bullying. Knowledge and awareness of teachers are very much needed in preventing bullying, because sometimes even small things can have a big impact on children's development in the future. This research was conducted using a descriptive qualitative approach through interviews and direct observation with six teachers at the school. It turned out that based on the interviews and observations, it was found that several forms of handling were carried out by the teacher with an average form of handling that was almost the same between one teacher and another. This is expected to be a form of information for teachers in dealing with bullying in schools.
\end{abstract}

Keywords: bullying; preschool children; school

Copyright (c) 2021 Nanda Pratiwi, Sugito.

$\triangle$ Corresponding author :

Email Address : nanda.pratiwi2809@gmail.com (Yogyakarta, Indonesia)

Received 1 May 2021, Accepted 15 September 2021, Published 18 September 2021 


\section{PENDAHULUAN}

Komisioner Perlindungan Anak Indonesia (KPAI) pada situs resminya https://www.kpai.go.id menuliskan bahwa di dalam kurun waktu 9 tahun ini dimulai dari 2011 sampai dengan 2019 tercatat ada 37.381 pengaduan untuk kekerasan terhadap anak dan untuk Bullying baik di dalam lingkup pendidikan maupun sosial media angkanya sendiri mencapai 2.473 laporan dan kasusnya terus meningkat. Di dalam kasus bully ini KPAI mengatakan bahwa kejadia siswa yang jarinya sampai harus diamputasi, hingga siswa yang yang menjadi korban di tentang hingga meninggal, menjadi gambaran yang ekstrem dan paling fatal dari intimidasi bullying fisik dan psikis yang dilakukan pelajar kepada teman-temannya pada Februari 2020

Bullying sendiri merupakan suatu bentuk tindakan yang sangat merugikan dan bertujuan untuk menggangu, menyakiti ataupun menyerang seseorang. Menurut Tirmidziani dkk 2018 bullying berasal dari kata bully yang artinya menggertak atau seseorang yang menganggu orang yang lemah atau dapat dikatakan bullying ialah penyalahgunaan kekuasaan yang berkelanjutan dalam suatu hubungan, melalui tindakan verbal, fisik, dan sosial yang berulang, yang menyebabkan kerugian fisik dan psikologis. Menurut Mahriza dkk 2020 Bullying ialah suatu bentuk perilaku kekerasan yang dilakukan, berupa pemaksanan baik secara psikologis maupun fisik terhadap anak yang dinilai lebih lemah dari sekelompok orang yang kuat. Menurut Arumsari \& Setyawan 2019 Bullying seringkali juga dilakukan secara berkelanjutan di dalam kurung waktu yang cukup lama, sehingga para korban bullying akan berada dalam keadaan cemas dan merasa terintimidasi. Bullying ini tentulah berbeda dengan bentuk perilaku agresif lain yang biasa dilakukan paling hanya satu kali kesempatan dan juga di dalam jangka waktu pendek. Bullying atau yang bisa di sebut penindasan merupakan suatu tindakan yang disengaja dimana seseorang melakukan tindakan negatif baiksecara fisik, verbal dan psikologis secara berulang-ulang kepada orang lain (Rahayu dkk , 2020).

Bullying ini dapat muncul pada saat masa kanak-kanak atau pun usia dini. Anak yang berada pada usia 3 tahun dapat ikut berpartisipasi di dalam tindakan bullying (Ambarini et al., 2018). Bullying ini juga dapat berpengaruh pada kegiatan bermain pada anak. Bullying dapat mengakibatkan anak menjadi lebih nyaman bermain sendiri ketimbang bermain dengan teman-temannya. Bullying merupakan suatu tindakan yang agresif, namun tidaklah semua bentuk tindak agresif digolongkan sebagai bullying, kecuali bila tindakan agresif itu dilakukan anak berulang-ulang oleh pelaku yang sama terhadap korban yang sama juga, dan perilaku tersebut memang diniatkan untuk menyakiti korban (Abubakar, 2018). Menurut Olweus (1997) Ciri khas dari para pembullying adalah tingkah laku mereka terhadap teman sebaya. Tetapi para pembullying seringkali juga agresif terhadap orang dewasa, baik guru maupun orang tua. Secara umum, pelaku intimidasi memiliki sikap yang lebih positif terhadap kekerasan dan penggunaan cara-cara kekerasan daripada siswa pada umumnya. Lebih jauh, mereka sering dicirikan oleh impulsif dan kebutuhan yang kuat untuk mendominasi orang lain.

Menurut Olweus (1997) Bullying dicirikan dengan tiga kriteria berikut: (a) itu adalah perilaku agresif atau "tindakan merugikan" yang disengaja; (b) yang dilakukan "berulang kali dan sepanjang waktu" dan (c) dalam hubungan interpersonal yang ditandai dengan ketidak seimbangan kekuasaan. Menurut Widiyanti, 2019 ada beberapa jenis-jenis dari bullying, yaitu: (1) Bullying Fisik, ialah salah satu bentuk bullying yang paling banyak di temukan di sekolah misalnya: anak memukul, menendang, mecambuk, ataupun melakukan kekerasan yang berhubungan dengan fisik. (2) Bullying Sosial ialah sutu bentuk sikap yang dapat memberikan dampak yang tidak baik terhadap korban dan bertujuan untuk meremehkan korban, misalnya: mengucilkan, meremehkan, menghina. Sehingga dapat membuat korban menjadi depresi, cemas, terkucilkan sosial dan rendah diri. (3) Bullying Verbal, ialah suatu bentuk tingkah laku yang dapat menyerang psikologis dan emosi seseorang, misalnya: fitnah, 
pencemaran nama baik, kekerasan verbal, menahan informasi, mengucilkan, mengabaikan pendapat, mengancam, mengejek. (4) Cyber Bullying, misalnya: mengancam dan melecehkan seseorang via sosial media.

Anak prasekolah (PAUD) terkadang juga melakukan perilaku agresif, tapi jika perilaku ini dilakukan berulang-ulang dan dengan tujuan menakuti seseorang ataupun sekelompok anak lainnya, maka ini dapat juga dikatakan bahwa anak tersebut melakukan tindakan bullying (Dey Putri et al., 2020). Tidak dapat dipungkiri bahwa bullying ini dapat terjadi di lingkungan PAUD, di lingkungan ini anak akan berada pada tentang usia $4-6$ tahun yang mana itu adalah usia-usia awal anak dapat melakukan perundungan antar sesama temannya, dari hal yang kecil seperti merebut mainan temannya ataupun mendorong temannya sampai dengan tindakan kekerasan seperti memukul ataupun mencubit temannya. PAUD sendiri merupakan jenjang pendidikan dasar yang dapat memberikan sumbangsih terbesar pada pembentukan perilaku anak dalam rangka membentuk karakter anak agar terhindar dari perilaku bullying ini (Sakti \& Widyastuti, 2020). PAUD juga merupakan lingkungan sekolah yang pertama untuk anak sehingga di dalam lingkungan PAUD inilah anak sekaligus belajar bagaimana untuk bersosialisasi dengan teman sebayanya.

Bersadarkan dari berbagai penelitian yang telah di lakukan sebelumnya di temukan ada banyak sekali bentuk tindakan bullying yang ternyata di lakukan oleh anak di sekolah. Menurut penelitian yang dilakukan oleh Wahyuni \& Pransiska 2019 di sebutkan bahwa terdapat tiga jenis perilaku bullying yang kerap terjadi di lingkungan Taman Kanak-Kanak, diantaranya adalah bullying fisik, bullying verbal, dan bullying psikologis. Bullying Fisik yang umumnya dilakukan oleh anak seperti mendorong, menendang, memukul, mencubit, dan juga merusak barang/mainan milik temannya. Bullying Verbal umumnya yang dilakukan anak seperti mengejek, mengolok, memarahi, menteriaki, serta juga anak mengancam/mengintimadasi temannya. Dan Bullying psikologi yang di lakukan anak seperti mengucilkan, menyendiri/murung, menangis karena ditakuti, dan Menangis karena ditertawakan. Perilaku tersebut kerap terjadi berkali-kali dan juga berulang setiap harinya.

Temuan hasil penelitian yang di lakukan oleh Purnama dkk 2018 di salah satu Tanam Kanak - Kanak yang ada di makasar di temukan bahwa ternyata perilaku bullying juga kerap terjadi. Beberapa perilaku bullying yang sering dilakukan oleh anak adalah Bullying Verbal yang berupa memanggil dengan sebutan lain atau mengejek, dan Bullying fisik yang terjadi di sekolah tersebut berupa memukul, menendang, merampas milik temannya, mrusak mainan milik temannya, memelintir lengan, mendorong, melempar dan mengancam. Namun dari beberapa hal ini Bullying fisik merupakan hal yang paling sering trejadi di lingkungan sekolah tersebut. Penelitian yang di lakukan oleh Arumsari \& Setyawan, 2019 memukan bahwa guru di Taman Kanak-Kanak (TK) bahwa tanda-tanda bullying telah tampak di anak usia dini dengan tanda-tanda kemunculnya dapat bentuk verbal dan non verbal. Untuk bullying dalam bentuk verbal misalnya anak memanggil temannya dengan nama julukan ataupun berteriak pada anak yang lebih muda umurnya dam bullying non verbal misalnya menendang, memukul, mendorong temannya yang badannya lebih kecil, dan lain-lain.

Disinilah fungsi guru untuk dapat menangani perilaku bullying sesegera mungkin dengan cara yang tepat. Penanganan yang tepat tersebut, dapat diberikan kepada pelaku, korban, dan juga teman-teman lain yang ikut menyaksikan perilaku bullying tersebut. Penanganan yang dilakukan di sekolah sebaiknya dilakukan langsung oleh para guru. maka dari itu, sebelum perilaku bullying terjadi, guru perlu untuk dapat mengetahui tentang bentuk bullying yang ada di sekolah sehingga guru mampu mencegah terjadinya bullying sedini mungkin. Pencegahan bullying di sekolah tersebut dimulai sejak anak-anak berada di Pendidikan Anak Usia Dini (PAUD). Pencegahan yang dilakukan sedini mungkin akan lebih efektif di dalam menangani bullying karena berdasarkan studi yang dilakukan oleh Akerman et al., 2018 mengatakan bahwa bullying yang dilakukan memiliki konsekuensi jangka pendek bagi pelaku seperti perasaan subjektif dari malaise pasca serangan dan untuk jangka panjang dapay mengakibatkan meningkatnya keterlibatan dalam kekerasan di kemudian harinya. 
Menurut Akerman et al., 2018 pendidikan, nilai-nilai keluarga, dan komunikasi antara orang tua dan anak dianggap sebagai kontributor utama pencegahan bullying. Data hasil penelitian yang di lakukan oleh Arkeman dkk menunjukkan bahwa komunikasi, secara umum, dengan anak, sekolah, atau guru, dipandang sebagai reaksi utama yang perlu dilakukan orang tua ketika anak mereka menjadi agresor atau korban perundungan.

Pada penelitian sebelum yang telah dilakukan pada umumnya melihat bagaimana bentuk-bentuk bullying yang pada umumnya di lakukan oleh anak di sekolah dan apa saja dampak-dapak dari bullying ono. sedangkan pada penelitian kali ini yang dilakukan oleh peneliti lebih memfokuskan kepada bagaimana sebenarnya bentuk dari pola penanganan para guru secara langsung di lapangan di dalam menghadapi bllying di lingkungan sekolah.

\section{METODOLOGI}

Penelitian ini menggunakan model pendekatan kualitatif deskriptif yang mana penelitian ini bertujuan guna untuk mengungkap bagaimana bentuk Pola Penanganan Guru Dalam Menghadapi Bullying di PAUD. Penelitian kualitatif adalah penelitian yang dilakukan dengan mengandalkan pengumpulan data kualitatif (data nonnumerik, seperti kata-kata dan foto-foto). Peneliti kualitatif cenderung mengandalkan mode induktif dari metode ilmiah, dan tujuan utama dari jenis penelitian ini adalah eksplorasi atau penemuan (Christensen, et al., 2014). Untuk waktu wawancara yang di gunakan disesuaikan antara waktu yang dimiliki oleh narasumber dengan waktu yang dimiliki peneliti. Narasumber di dalam penelitian ini ditentukan melalui purposive sampling yang mana melibatkan enam narasumber sesuai dengan kriteria yang telah ditentukan sebelumnya, yaitu narasumber berprofesi sebagai guru pada jenjang PAUD. Wawancara dilakukan dengan jarak jauh secara daring dan secara langsung setelah keempat narasumber ini menyetujui dan berkenan untuk dapat diwawancarai mengenai bagaimana peran guru PAUD dalam penanganan bullying yang ada di sekolah. Keenam orang narasumber sumber berasal dari latar belakang sarjana pendidikan dan dengan rentan lama mengajar ada yang sedari tahun 1980an hingga 2006.

Teknik analisis data yang dilakukan dalam penelitian ini menggunakan langkahlangkah mengumpulkan data dari studi literatur yang berkaitan dan wawancara lalu dilakukan reduksi pada data, pembahasan, dan di tariklah kesimpulan dari penelitian ini. Adapun desain penelitian pada gambar :

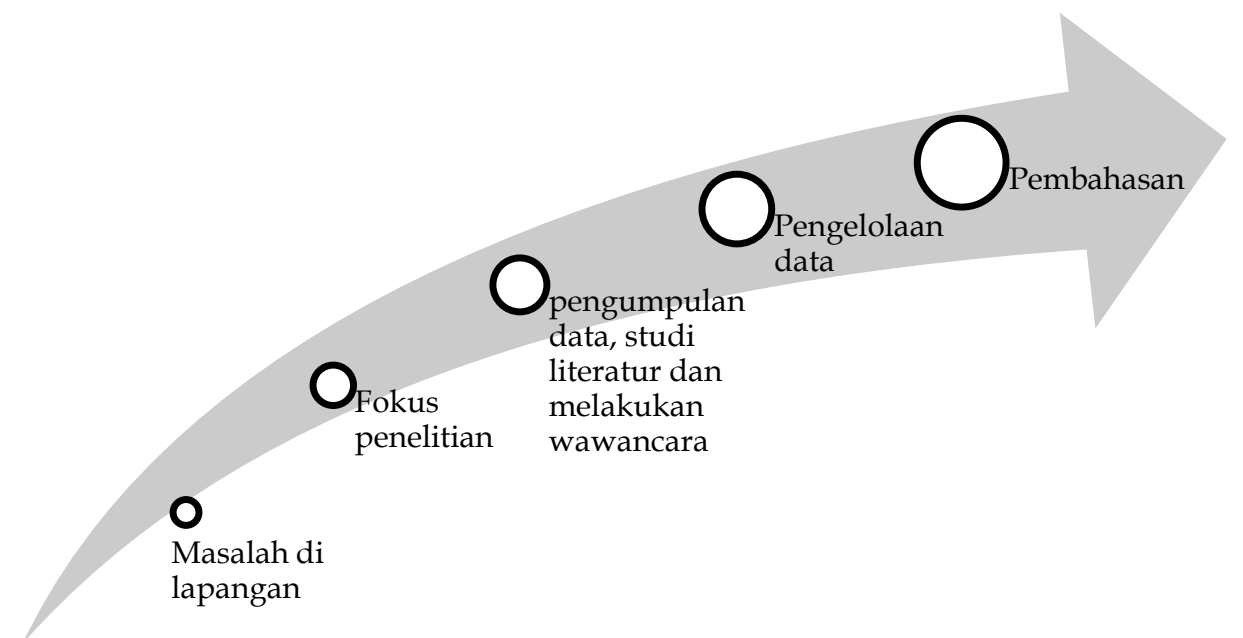

Gambar 1. Desain Penelitian

\section{HASIL DAN PEMBAHASAN}

\section{Bullying pada anak}

Bullying pada anak-anak prasekolah tidak selalu mudah untuk dapat diidentifikasi, karena anak-anak pada saat usia tersebut dapat menunjukkan perilaku agresif karena 
keterbatasan dalam perkembangan kognitif dan verbal. Namun, penting bahwa guru pendidikan prasekolah untuk tidak meremehkan keparahan atau frekuensi perilaku tersebut dan belajar membedakan antara konflik khas dan perilaku yang muncul dari intimidasi prasekolah (Douvlos, 2019). Maka dari itu untuk guru khususnya guru PAUD dan juga TK perlulah memiliki sebuah pengetahuan yang baik agar guru dapat siap untuk menghadapi apabila terjadi perilaku bullying di sekolah, dan ikut mengurangi atau mencegah dampak negatif dari bullying (Puspita \& Herdiana, 2020).

Pada wawancara yang telah dilakukan dengan 6 orang guru TK yang ada di kota jambi di temukan bahwa semua guru pernah menemukan kasus bullying yang terjadi di dalam kelas, kasus bullying yang di temui ini sangat beragam. Ada beberapa yang menemukan kasus berupa tindakan mengejek (menjulurkan lidah) kepada temannya, mendorong teman, menganggu teman yang sedang belajar, atau bahkan merampas mainan milik temannya. Namun ada juga beberapa kejadian yang dimana anak menghasut temannya untuk tidak berteman dengan salah satu teman lainnya. Hal ini di sebut dengan Rational Bullying yang mana ialah di dasarkan pada tidak ingin berteman dengan salah satu anak atau meberitahu anak lainnya untuk tidak bermain dengan anak itu, menolak anak lain untuk bergabung dalam permainan, merusak permainan, menghancurkan persahabatan, mencegah beberapa anak untuk bermain atau berkomunikasi dengan orang lain, dan mengabaikan beberapa anak lainnya (Iraklis, 2020). Ada juga beberapa guru yang menemukan kasus anak yang sering menjadi korban bullying oleh beberapa anak SD yang kebetulan berada di dalam satu lingkungan sekolah dengan TK, namun kasus ini berupa mengambil makanan anak TK tersebut beberapa kali. Ada juga kasus dimana anak ini selain dia suka mengganggu temannya tetapi dia juga berani untuk memukul gurunya atau melawan gurunya.

\section{Upaya penanganan bullying}

Di dalam wawancara ini guru mengatakan bahwa tindakan pertama yang guru lakukan pada saat bullying ini terjadi adalah dengan menegur sang anak terlebih dahulu dan memberi tahu bahwa hal tersebut merupakan tindakan yang kurang terpuji untuk dilakukan. Guru juga berusaha untuk mencari tahu terlebih dahulu faktor-faktor mengapa perubahan sikap ini terjadi pada anak. Atau apa bila hal itu sering terulang, beberapa guru biasanya berinisiatif untuk langsung berbicara berdua dengan anak tersebut sambil memberi pemahaman pada anak terkait perilakunya yang terkadang suka membullying temannya. Penanganan awal yang dilakukan guru dapat dilihat pada tabel 1.

Dari hasil wawancara juga di dapatkan bahwa apa bila hal ini terus menerus terjadi maka para guru akan mengkomunikasikan dengan orang tua terkait perilaku anaknya di sekolah. Sebenarnya guru akan selalu mengkomunikasikannya dengan orang tua, ntah itu perilaku baik ataupun buruk, guru tetap harus selalu mengkomunikasikan dan membilacakannya dengan orang tua agar guru mengetahui faktor-faktor sebenarnya penyebab perilaku itu muncul, karana terkadang faktor lingkungan tempat tinggallah yang paling banyak berpengaruh di dalam pembentukan sikap pada anak. Hal ini sejalan dengan pendapat dari Zahroh \& Na'imah, 2020 yang mengatakan bahwa Lingkungan merupakan bagian yang sangat penting di dalam perkembangan sikap anak baik lingkungan keluarga, lingkungan sekolah yang juga termasuk lingkungan teman sebaya, lingkungan masyarakat dan lingkungan fisik tempat tinggal anak. Pada wawancara ini ada seorang guru yang menyebutkan bahwa ada satu anak yang telah bersekolah di sana sejak tahun lalu namun perilakunya di tahun sekarang cukup berubah lebih sering mengganggu dan menjahili temannya, ternyata setelah di bicarakan dengan orang tua hal ini terjadi karna pada selama masa pandemi anak tersebut di masukan ke sekolah madrasah yang kebanyakan muridnya berusia lebih tua dari pada anak. Semua bentuk pengetahuan yang baru diketahui oleh anak baik yang bersifat positif ataupun yang bersifat negatif akan diterima, ditanggapi lalu kemudian akan ditiru oleh anak usia dini sesuai dengan bentuk kepribadian masing-masing. Karena anak usia dini merupakan seorang peniru terbaik, dan lingkungan sekitarnya adalah 
pelaku atau role model bagi anak (Tirmidziani et al., 2018). Hal ini menjadi salah satu faktor penyebab anak bersikap lebih agresif dan suka mengganggu temannya di bandingkan pada saat sebelum pandemi yang anak lebih banyak bersekolah dan bermain dengan teman-teman seusianya.

Tabel 1 Penanganan awal yang dilakukan guru

\begin{tabular}{cl}
\hline Guru & \multicolumn{1}{c}{ Hasil wawancara } \\
\hline Guru 1 & $\begin{array}{l}\text { Pada saat hal itu terjadi yang pertama kali kami lakukan adalah menegur anak } \\
\text { tersebut namun berusaha dengan bahasa yang lembut dan tidak menghakimi } \\
\text { anak. }\end{array}$ \\
Guru 2 & $\begin{array}{l}\text { Saya akan bertanya terlebih dahulu apa yang terjadi antara kedua anak tersebut, } \\
\text { lalu akan saya beritahu apa hal-hal yang seharusnya boleh dilakukan dan tidak } \\
\text { boleh dilakukan oleh anak }\end{array}$ \\
Guru 3 & $\begin{array}{l}\text { Memberitahu kepada anak apa bila mengganggu teman itu merupakan hal yang } \\
\text { tidak baik, lalu saya akan berkonsultasi dengan orang tua dari anak tersebut. }\end{array}$ \\
Guru 4 & $\begin{array}{l}\text { Pada saat ada anak yang mengejek-ngejek temannya yang terkadang } \\
\text { menggunakan baju yang berbeda dengan temannya maka saya mencoba } \\
\text { menjelaskan pada anak-anak lain mengapa ia menggunakan baju yang berbeda. }\end{array}$ \\
Guru 5 & $\begin{array}{l}\text { Saya mencoba untuk menanamkan nilai-nilai agama pada anak, seperti } \\
\text { menceritakan kisah-kisah tauladan nabi atau dongeng-dongeng yang bertema } \\
\text { nilai kebersamaan } \\
\text { Ada anak yang sering di ganggu oleh anak sd yang ada di lingkungan sekolah } \\
\text { dengan sering di mintai makanannya oleh mereka, saya memberi penjelasan } \\
\text { pada anak untuk berani berbicara tpada mereka bahwa makanan itu merupakan } \\
\text { miliknya, agar ia tidak hanya diam saja. }\end{array}$ \\
Guru
\end{tabular}

Para guru juga menyebutkan bahwa berkomunikasi dengan orang tua merupakan salah satu kunci di dalam menentukan bagaimana cara untuk dapat meminimalisir perilaku ini terus-terusan terjadi, karena orang tua ialah orang yang paling dekat dengan anak. Durasi anak di dalam bertemu dengan orang tua tentulah lebih lama dibandingkan dengan guru di sekolah, sehingga dengan berdiskusi dengan orang tua terkait dengan perilaku anak akan mempermudah di dalam menemukan solusi yang terbaik. Arumsari \& Setyawan 2019 juga mengatakan bahwa komunikasi antara guru dan orang tua harus selalu terjalin selama anak bersekolah di sekolah tersebut. Salah satu bentuk cara komunikasi yang dapat dilakukan oleh guru dan orang tua adalah dengan cara mengadakan parenting. Di dalam program parenting ini, orang tua dapat mengetahui bentuk dari gaya pengasuhan yang tepat pada anak, bagaimana cara untuk mengatasi permasalahan yang sedang terjadi pada anak, dan pada umumnya seringkali orang tua tidak mengetahui dampak perilakunya terhadap perkembangan anak. Orang tua yang ikut terlibat di dalam proses pencegahan awal dari perilaku bullying pada anak juga dapat ikut memainkan peran penting dalam mendukung perkembangan pribadi anak mereka di masa yang akan datang (Bili \& Sugito, 2020).

Dari 6 orang guru yang menjadi sample mengatakan bahwa tidak ada pembelajaran khusus atau RPP yang fokus langsung membahas tentang bullying ini di sekolah, namun mereka hanya mencoba untuk menyisipkan materi-materi tentang hal-hal yang boleh di lakukan dan tidak di lakukan oleh anak. Ada salah satu guru yang menjadi guru agama di sekolah TK mengatakan bahwa biasanya guru tersebut menjelaskan pada anak tentang teladan-teladan nabi atau sifat-sifat yang di benci oleh Allah swt. Atau untuk guru-guru yang lain pada umunya mereka mencoba untuk memberikan materi tentang bullying secara sederhana kepada anak di waktu-waktu setelah belajar menjelang makan atau pada saat-saat penutupan sebelum pulang. Atau guru kelas yang lain mencoba untuk memberi pemahaman pada anak tentang perilaku yang pantas ataupun tidak pantas di lakukan oleh anak di selasela anak makan dan menjelang pulang. 
Sebagian guru yang di wawancarai mengatakan bahwa sebenarnya terkadang anak seringkali mengganggu temannya pada awal-awal masuk sekolah untuk menarik perhatian temannya yang lain, namun terkadang hal-hal seperti ini apabila terjadi dalam waktu yang panjang dan di biarkan maka lama kelamaan hal tersebut dapat menuju ke perilaku bullying. Apa lagi terkadang anak bila tidak segera di beri tahu bahwa perilakunya tersebut itu salah mereka akan melakukan hal itu terus menerus, ini sejalan dengan penelitian yang dilakukan oleh Kirves \& Sajaniemi, 2012 bahwa terkadang anak-anak tidak selalu menyadari bahwa halhal seperti pengucilan ataupun mengejek yang mereka lakukan dapat menjadi bullying.

Berdasarkan wawancara yang telah di lakukan dengan guru, peneliti menemukan beberapa bentuk pola penanganan yang di lakukan oleh guru di sekolah. Hal-hal dapat di lakukan guru untuk menangani ataupun meminimalisir terjadinya bullying adalah : (1) apabila hal itu terjadi guru haruslah memberi tahu anak bahwa perbuatannya tersebut merupakan tindakan yang kurang terpuji, (2) memberi tahu anak hal-hal apa saja yang boleh dan tidak boleh di lakukan, misalnya sesame teman haruslah saling membantu atau sesama teman tidak boleh saling menyakiti, (3) berikan pemahaman agama pada anak, atau apabila anak yang beragama muslim dapat di ceritakan tentang cerita nabi, (4) apabila hal ini terjadi lagi maka guru haruslah mengkomunikasikan ini dengan orang tua untuk mendapatkan solusi yang terbaik untuk perkembangan anak.

Hal ini juga sejalan dengan hasil dari temuan Arumsari \& Setyawan 2019 Guru haruslah mengetahui berbagai macam cara mencegah bully ini terjadi, guru juga harus mengetahui bagaimana cara untuk memberikan bentuk pembelajaran yang dapat dijadikan contoh anak dalam mengatasi bullying ini. Beberapa hal yang dapat dilakukan oleh guru untuk mencegah terjadinya bullying di Taman Kanak-Kanak (TK), yaitu: (1) Melatih siswa untuk lebih asertif; (2) Mengawasi siswa selama di sekolah; (3) Memberikan materi pembelajaran untuk anak yang berkaitan dengan bullying melalui bermain; (4) Mengadakan kegiatan Parenting.

\section{SIMPULAN}

Masih banyak sekali kasus bullying yang terjadi di lingkungan sekolah dan cukup disadari oleh guru. Pada saat mengetahui hal itu terjadipun guru akan langsung memberi tahu anak tentang perilakunya yang salah secara baik dan tidak menghakimi anak. Walaupun tidak ada bentuk pembelajaran atau rpp khusus yang membahas tentang bullying namun guru tetap berupaya untuk tetap menyisipkan bentuk-bentuk pembelajaran karakter pada anak. Guru juga harus selalu berusaha untuk tetap berkomunikasi dengan orang tua untuk membahas tentang perkembangan anak, sedikit banyak perubahan anak di sekolah haruslan selalu dapat dipantu oleh orang tua.

\section{UCAPAN TERIMA KASIH}

Terima kasih kepada berbagai pihak yang telah membantu penulis. Khususnya para guru yang sudah bersedia melakukan wawancara dan juga bapak dosen yang telah membantu dalam membimbing penulis dalam menyelesaikan penelitian ini.

\section{DAFTAR PUSTAKA}

bubakar, S. R. (2018). Mencegah Lebih Efektif Dari Pada Menangani (Kasus Bullying Pada Anak Usia Dini). Jurnal Smart Paud, 1(1), 1. https://doi.org/10.36709/jspaud.v1i1.3514

Akerman, L., Borsa, J. C., Landim, L., \& Bienemann, B. (2018). Brazilian caregivers' conception on child bullying. Psicologia: Reflexao e Critica, 31(1). https:// doi.org/10.1186/s41155-018-0113-0 
Ambarini, R., Indrariani, E., \& Zahraini, A. (2018). Antisipasi Pencegahan Bullying Sedini Mungkin: Program Anti Bullying Terintegrasi Untuk Anak Usia Dini. Journal of Dedicators Community, 2(2), 64-82. https://doi.org/10.34001/jdc.v2i2.587

Arumsari, A. D., \& Setyawan, D. (2019). Peran Guru dalam Pencegahan Bullying di PAUD. Motoric, 2(1), 34-43. https:// doi.org/10.31090/paudmotoric.v2i1.739

Bili, F. G., \& Sugito, S. (2020). Perspektif Orang Tua Tentang Perilaku Bullying Anak TK: ditinjau dari Tingkat Pendidikan. Jurnal Obsesi : Jurnal Pendidikan Anak Usia Dini, 5(2), 1644-1654. https://doi.org/10.31004/obsesi.v5i2.939

Dey Putri, L. A., Yetti, E., \& Hartati, S. (2020). Pengaruh Keterlibatan Orangtua dan Regulasi Diri terhadap Perilaku Bullying Anak Usia Dini. Jurnal Obsesi : Jurnal Pendidikan Anak Usia Dini, 4(2), 715. https:// doi.org/10.31004/obsesi.v4i2.438

Douvlos, C. (2019). Bullying in preschool children. Psychological Thought, 12(1), 131-142. https://doi.org/10.5964/psyct.v12i1.284

Iraklis, G. (2020). Early childhood educators' experiences of bullying episodes: a qualitative approach. European Early Childhood Education Research Journal, 28(6), 774-788. https://doi.org/10.1080/1350293X.2020.1836581

Johnson, Burke, \& Christensen, Larry. (2014). Educational Research: Quantitative, Qualitative, and Mixed Approaches- Fifth edition

Kirves, L., \& Sajaniemi, N. (2012). Bullying in early educational settings. Early Child Development and Care, 383-400. https:// doi.org/10.1080/03004430.2011.646724

Mahriza, R., Rahmah, M., \& Santi, N. E. (2020). Stop Bullying: Analisis Kesadaran dan Tindakan Preventif Guru pada Anak Pra Sekolah. Jurnal Obsesi : Jurnal Pendidikan Anak Usia Dini, 5(1), 891-899. https:// doi.org/10.31004/obsesi.v5i1.739

Olweus, D. (1997). Bully/victim problems in school: Facts and intervention. European Journal of Psychology of Education, 12(4), 495-510. https:// doi.org/10.1007/BF03172807

Purnama, F., Herman, H., \& Saodi, S. (2018). Perilaku Bullying Pada Anak Di Taman KanakKanak Aisyiyah Bustanul Athfal I Cabang Bara-Baraya Kota Makassar. Publikasi Pendidikan, 8(1), 41. https:// doi.org/10.26858/publikan.v8i1.4480

Puspita, S. A. L., \& Herdiana, I. (2020). Penelitian Aksi Terhadap Guru PAUD dan TK: Meningkatkan Pengetahuan Pendidik Tentang Bullying di Sekolah melalui Kegiatan \begin{tabular}{l|lll} 
Psikoedukasi I Jurnal Psikologi Udayana. & 7(2),
\end{tabular} https://doi.org/10.24843/JPU.2020.v07.i02.p01

Rahayu, P., Rasyid, H., Puspitasari, C. A., \& Islamiyah, R. (2020). The Role of Teachers and Parents in Preventing Bullying in Early Childhood Education. 421(Icalc 2019), 359-362. https://doi.org/10.2991/assehr.k.200323.043

Sakti, S. A., \& Widyastuti, T. M. (2020). Implementasi Sekolah Bebas Bullying Pada Anak Usia Dini Melalui Komunikasi Positif Guru. Jurnal Ilmiah Kajian Ilmu Anak Dan Media Informasi PAUD, 5(2), 99-107.

Tirmidziani, A., Farida, N. S., Lestari, R. F., Trianita, R., Khoerunnisa, S., \& Khomaeny, E. F. F. (2018). Upaya Menghindari Bullying pada Anak Usia Dini. 2(1), 1-8. https:/ / doi.org/10.35568/earlychildhood.v2i1.239

Wahyuni, V., \& Pransiska, R. (2019). Perilaku bullying pada Anak Usia 5-6 Tahun Studi Kasus di Taman Kanak-Kanak. Journal of Family, Adult, and Early Childhood Education, 1(2), 160-166. https://doi.org/10.5281/zenodo.2650150

Widiyanti, W. (2019). Mengenal Perilaku Bullying di Sekolah. ISLAMIC COUNSELING: Jurnal Bimbingan Dan Konseling Islam, 3(1). https:// doi.org/10.31316/g.couns.v1i1.37

Zahroh, S., \& Na'imah. (2020). Peran lingkungan sosial terhadap pembentukan karakter anak usia dini di jogja green school. Jurnal PG-PAUD Trunojoyo: Jurnal Pendidikan Dan $\begin{array}{llll}\text { Pembelajaran Anak Usia } & \text { 1-9. }\end{array}$ https://doi.org/10.21107/pgpaudtrunojoyo.v7i1.6293 